\title{
Washing and Extraction of Metals from Two Industrially Contaminated Soils: A Prognostication for Techno- economic Clean up
}

\author{
L. Mgbeahuruike, S. S. Potgieter-Vermaak, L. van Dyk, J. H. Potgieter, M. U. Dike, E. I. Emereibeole, \\ R. F. Njoku-Tony, C. E. Ihejirika, C. N. Uyo, F. A. Edo, and K. M. Iwuji
}

\section{ABSTRACT}

The extraction and recovery of metals from contaminated soil has become inevitable considering the increasing premium placed on environmental and human health protection as well as predicted shortfalls in primary metal production. In this study, metal extraction from two industrially contaminated soils (Copsa-mica [Rb-So] and Campina [Ro-PH]) were considered for process (column and heap) leaching configuration using different selected chelating substances; ethylene diamine tetraacetic acid [EDTA], ethylene diamine disuccinic acid [EDDS], acetylacetone [Hacac] and citric acid [CA]. The result confirms optimal recovery of EDTA columninduced-Rb-So over chelant-heap induced configuration and was adopted for economic prediction using two possible $(60 \%$ and $100 \%)$ recycled scenarios. The $100 \%$ recycled scenario resulted in a viable economic process sufficient enough to offset clean-up cost. Metal separation and recovery from M-EDTA complex could be facilitated with the use of $\mathrm{H}_{2} \mathrm{~S}$ gas precipitated in hydrogen flame combustion. The process economics predicted offered a probable prospect for metal separation from washing liquor.

Keywords: EDTA, EDSS, Extraction, $\mathrm{H}_{2} \mathrm{~S}$ gas, Metals, Washing.
Published Online: October 18, 2021

ISSN: $2684-4478$

DOI :10.24018/ejchem.2021.2.4.74

L. Mgbeahuruike*

Department of Environmental Technology, Federal University of Technology, Owerri (FUTO), Nigeria. S. S. Potgieter-Vermaak

Chemistry and Environmental Science Division, School of Science and the Environment, Manchester Metropolitan University, Chester Street, Manchester, M1 5GD, UK.

L. van Dyk

School of Chemical and Metallurgical Engineering, University of the Witwatersrand, P.O. Box X3, Wits, 2050 , South Africa.

J. H. Potgieter

Chemistry and Environmental Science Division, School of Science and the Environment, Manchester Metropolitan University, Chester Street, Manchester, M1 5GD, UK.

M. U. Dike

Department of Environmental Technology, Federal University of Technology, Owerri (FUTO), Nigeria.

E. I. Emereibeole

Department of Environmental Technology, Federal University of Technology, Owerri (FUTO), Nigeria.

R. F. Njoku-Tony

Department of Environmental Technology, Federal University of Technology, Owerri (FUTO), Nigeria.

C. E. Ihejirika

Department of Environmental Technology, Federal University of Technology, Owerri (FUTO), Nigeria. C. N. Uyo

Department of Environmental Technology, Federal University of Technology, Owerri (FUTO), Nigeria.

(e-mail: uyochijioke@yahoo.com)

F. A. Edo

Department of Environmental Technology, Federal University of Technology, Owerri (FUTO), Nigeria. K. M. Iwuji

Department of Environmental Technology, Federal University of Technology, Owerri (FUTO), Nigeria.

*Corresponding Author 


\section{BACKGROUND}

Contaminated soils are a real environmental concern [1], due to its detrimental impact on living organisms and ecosystems [2]. Amongst others, heavy metal contamination from agricultural waste, industrial effluents and wastes, and others, pose several challenges to society [3]. Heavy metal contamination typically include lead, cadmium, nickel and zinc, and ranges from 4000-30000 mg/kg for lead [4] and 40$1000 \mathrm{mg} / \mathrm{kg}$ for cadmium [4].

Soil washing is an established technology, which offers effective remediation of soil. This process involves the removal of contaminants through a chemical adsorption process by means of acid or chelating extractants [4]. The acid-removal process (e.g., weak organic acids like citric acid, oxalic acid or tartaric acid [5]-[7] is mainly $\mathrm{pH}$ driven and ultimately results in the dissolution of metals. The use of chelants often offer a more environmentally friendly option as acids can easily cause damage to the soil integrity [4]. Common chelants that are used include ethylenediaminetetraacetic acid (EDTA) [8], ethylenediamine-N, N'-disuccinic acid (EDDS) [9], and iminodisuccinic acid (IDSA) [10]. Chelate remediation need to be considered with care as not all of them are environmentally sound and therefore, recycling of any chelant is necessary.

There have been many studies reported on soil pollution and potential approaches to remediate it [7], [11]-[15]. The effectiveness of any remedial treatment will depend on type of washing agent, exposure / leaching time, $\mathrm{pH}$ conditions, interaction between the washing agent and the potentially toxic elements (PTE), stirring rate, solid:liquid ratio, temperature and process configuration.

The aim of this investigation was, firstly, to compare the efficiency of two commonly employed process configurations of extraction, namely heap and column leaching, on two industrially contaminated soils with a number of different chelating agents and organic acids. In the second place, it was to determine whether the income from the extracted metals can offset the expenditure of the chelating solution and make the process economically viable when using the overall most effective soil washing/leaching agent, i.e., EDTA. The contribution of this paper does not only lie in the comparison of the efficiency of the two industrial processes for the soil washing or determining the most effective soil washing agent, but also in the estimation of the process economics to determine the financial viability of the approach and the illustration of a workable approach to render the soil useful again for agricultural and socioeconomic purposes.

\section{ECONOMIC EVALUATION OF EXTRACTING METALS FROM CONTAMINATED SOILS}

The study considered the remediation of two Romanian (Copsa-mica [Rb-So] and Campina [Ro-PH]) soils for metal recovery using two different process (column and heap) configurations. However, the assertion drawn from the experimental analysis conducted by the Author at Manchester Metropolitan University laboratory, UK [16] attests that
Column-induced $\mathrm{Rb}$-So gave the highest recoveries of metals and the process consumed far less leachant solution than the heap process. It was decided to use this soil to investigate if the proposed remediating process using different chelating agents is economically viable because if it is not viable for the best extraction of metals it would not be for any of the other cases which yielded worse extractions. A value unit of $1 \mathrm{~kg}$ of contaminated $\mathrm{Rb}$-So soil was chosen as a basis for all calculations. The price of the metals and the chelating agents were researched and recorded as stated in Table I. Next the amount of chelating agent necessary had to be determined. From literature it was found that solid to liquid ratios varied from $1: 5$ to $1: 25$ [9], [17], [18]. In this investigation a solid:liquid ratio of $1: 10$ was chosen for the economic evaluation. This resulted in $10 \mathrm{~L}$ of leaching solution used per $\mathrm{kg}$ of contaminated soil. Literature has shown that the chelate concentration for the most effective extraction of heavy metals were $0.035 \mathrm{M}$ [19]. Other studies have used 0.01-0.1 M solutions [20]. Literature has also shown that a higher amount of metals can be extracted by consecutive washes of the soil with the chelating solution. A total of 4 washes yielded the optimum amount of extracted metals from the soil [10], [19]. Mohamed et al [10] found that after these washes up to $40 \%$ of the chelating solution was lost. Zeng et al [21] found that only 20-24\% of the chelating solution was lost after seven washes. For the economic evaluation two scenarios were assumed as illustrated in Fig. 2. The first scenario will account for a worst case scenario of $40 \%$ chelating solution loss and the second scenario will account for $100 \%$ recycling of chelating solution. For scenario 1 , a make-up feed of $4 \mathrm{~L}$ (assuming density of $1 \mathrm{~kg} / \mathrm{L}$ ) leaching solution was taken into account in the economic evaluation.

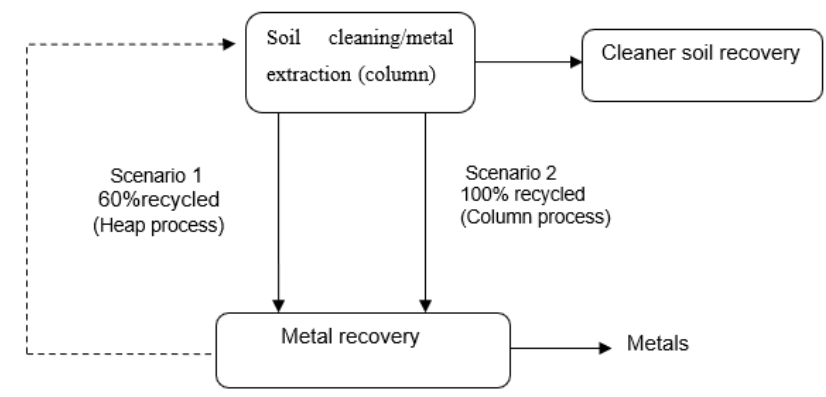

Fig. 1. Simplified block flow of a proposed remediation/recovery scenario. The economic evaluation was done as follow:

$$
n=C \cdot V
$$

$$
\begin{aligned}
& n=0.035 \frac{\mathrm{mol}}{\mathrm{L}} \cdot 10 \frac{\mathrm{L}_{\text {sol }}}{\mathrm{kg}_{\text {soil }}}=0.35 \frac{\mathrm{mol}_{\text {chel }}}{\mathrm{kg}_{\text {soil }}} \\
& m=n \cdot M M=0.35 \cdot M M_{\text {Chel }}=x \frac{\mathrm{kg}_{\text {chel }}}{\mathrm{kg} \text { soil }}
\end{aligned}
$$

$$
\text { Basis is } 1 \mathrm{~kg}_{\text {soil }} \rightarrow x k g_{\text {chel }}
$$

Scenario 1: Extractant needed

$$
\begin{aligned}
& =0.4 \cdot x(40 \% \text { loss of } \mathrm{sol}) \\
& =y \mathrm{~kg}_{\text {chel }} \text { needed }
\end{aligned}
$$




$$
\begin{gathered}
\text { Scenario 2: Exractant needed }=0 \cdot x \\
=0 \mathrm{~kg}_{\text {chel }} \text { needed }
\end{gathered}
$$

$$
\text { Chelate expense }=y \cdot c
$$

Where $\mathrm{c}$ is the price of the chelate in $\$ / \mathrm{kg}$.

$$
c=z \frac{\$}{k g_{\text {soil }}}
$$

The total revenue of the metals extracted from $1 \mathrm{~kg}$ of $\mathrm{Rb}$ So contaminated soil for the different chelating agents were as follow:

TABLE I: PRICES OF METALS AND CHELATING SUBSTANCES QUOTED FORM WWW.IME.COM/METAL PRICES.COM AND ALIBABA.COM

\begin{tabular}{cccccc}
\multicolumn{7}{c}{ RESPECTIVELY } \\
\hline Metal & $\mathrm{Cd}$ & $\mathrm{Cu}$ & $\mathrm{Ni}$ & $\mathrm{Pb}$ & $\mathrm{Zn}$ \\
$(\$ / \mathrm{kg})$ & $(1.157)$ & $(6.418)$ & $(11.26)$ & $(1.028)$ & $(2.993)$ \\
\hline Chelant & EDTA & EDDS & Hacac & \multirow{2}{*}{$\mathrm{CA}(2.8)$} \\
$(\$ / \mathrm{kg})$ & $(2.9)$ & $(5.65)$ & $(3.13)$ & \multicolumn{2}{|c}{} \\
\hline
\end{tabular}

TABLE II: AMOUNT OF METAL EXTRACTED FROM RB-SO SOIL USING DIFFERENT CHELATING AGENTS

\begin{tabular}{|c|c|c|c|c|c|c|}
\hline $\begin{array}{c}\text { Chelating } \\
\text { agent }\end{array}$ & $\begin{array}{c}\text { Revenue } \\
\text { from Cd } \\
(\$ / \mathrm{kg})\end{array}$ & $\begin{array}{c}\text { Revenue } \\
\text { from } \mathrm{Cu} \\
(\$ / \mathrm{kg})\end{array}$ & $\begin{array}{l}\text { Revenue } \\
\text { from Ni } \\
(\$ / \mathrm{kg})\end{array}$ & $\begin{array}{c}\text { Revenue } \\
\text { from } \mathrm{Pb} \\
(\$ / \mathrm{kg})\end{array}$ & $\begin{array}{l}\text { Revenue } \\
\text { from } \mathrm{Zn} \\
(\$ / \mathrm{kg})\end{array}$ & $\begin{array}{c}\text { Total } \\
\text { income } \\
\text { from } \\
\text { metals } \\
(\$ / \mathrm{kg})\end{array}$ \\
\hline EDTA & $5.2 \mathrm{E}-02$ & $6.5 \mathrm{E}-01$ & $5.9 \mathrm{E}-02$ & $1.6 \mathrm{E} 4$ & $7.3 \mathrm{E} 4$ & 9.661 \\
\hline EDDS & $3.1 \mathrm{E}-02$ & $6.6 \mathrm{E}-01$ & 5.3E-02 & $3.5 \mathrm{E}-01$ & $6.8 \mathrm{E} 4$ & 7.894 \\
\hline Hacac & $1.7 \mathrm{E}-02$ & $6.8 \mathrm{E}-01$ & $3.4 \mathrm{E}-01$ & $3.9 \mathrm{E}-02$ & $5.7 \mathrm{E} 4$ & 6.776 \\
\hline CA & 4.6E-02 & $6.2 \mathrm{E}-01$ & 5.9E-02 & $1.0 \mathrm{E} 4$ & $6.7 \mathrm{E} 4$ & 8.425 \\
\hline
\end{tabular}

\begin{tabular}{ccccc}
\hline \multirow{2}{*}{$\begin{array}{c}\text { Loading } \\
(\mathrm{mg} / \mathrm{kg})\end{array}$} & $\begin{array}{c}\text { Metal } \\
\text { leached } \\
(\mathrm{mg} / \mathrm{kg})\end{array}$ & $\begin{array}{c}\text { Metal } \\
\text { leached } \\
(\mathrm{mg} / \mathrm{kg})\end{array}$ & $\begin{array}{c}\text { Metal } \\
\text { leached } \\
(\mathrm{mg} / \mathrm{kg})\end{array}$ & $\begin{array}{c}\text { Metal } \\
\text { leached } \\
(\mathrm{mg} / \mathrm{kg})\end{array}$ \\
\hline $\mathrm{Cd}[50]$ & 45 & 26.4 & 15 & 40 \\
$\mathrm{Cu}[550]$ & 102 & 103.5 & 105.5 & 96.6 \\
$\mathrm{Ni}[650]$ & 5.3 & 4.7 & 29.8 & 5.3 \\
$\mathrm{~Pb}[1590]$ & 1578.8 & 339.1 & 38.8 & 1003.4 \\
$\mathrm{Zn}[2160]$ & 2446.2 & 2283.5 & 1911.9 & 2222 \\
\hline
\end{tabular}

TABLE III: CALCULATION OF THE TOTAL INCOME FROM METALS

\begin{tabular}{|c|c|c|c|c|}
\hline $\begin{array}{c}\text { Chelating } \\
\text { agent }\end{array}$ & $\begin{array}{c}\text { Cost of } \\
\text { chelating } \\
\text { agent }(\$ / \mathrm{kg} \\
\text { agent) }\end{array}$ & $\begin{array}{c}\text { Scenario 1: } \\
40 \% \\
\text { make-up } \\
\text { chelate } \\
\text { feed cost } \\
(\$ / \mathrm{kgsoil}) \\
\end{array}$ & $\begin{array}{c}\text { Scenario } 1 \\
(40 \% \\
\text { make-up } \\
\text { chelate) } \\
\text { gross profit } \\
(\$ / \text { kgsoil }) \\
\end{array}$ & $\begin{array}{c}\text { Scenario } 2 \\
(0 \% \text { make- } \\
\text { up chelate }) \\
\text { gross profit } \\
(\$ / \mathrm{kgsoil})\end{array}$ \\
\hline EDTA & 2.9 & 0.118 & 0.178 & 0.296 \\
\hline EDDS & 5.65 & 0.231 & 0.347 & 0.578 \\
\hline Hacac & 3.13 & 0.044 & 0.065 & 0.109 \\
\hline CA & 2.8 & 0.075 & 0.113 & 0.188 \\
\hline
\end{tabular}
EXTRACTED FROM RB-SO SOIL USING DIFFERENT CHELATING AGENTS

TABLE IV: CALCULATION OF GROSS PROFIT WHEN $60 \%$ AND $100 \%$

As can be seen from Table IV, when only $60 \%$ of the EDTA is recycled (scenario 1 ) it is not economically viable to extract metals from the aforementioned soils, because, the total income from metal $(\$ / \mathrm{kg})$ will be lost by 3.854 . Heap leaching extracted the most metals and even with this taken into account none of the chelating agents produce a profit in the process of leaching metals from contaminated soil when $40 \%$ make-up chelate is needed.

However when $100 \%$ of the EDTA can be recycled the cost of the make-up EDTA is reduced to $\$ 0$ and the revenue from Table III becomes the gross revenue (9.661 $\$ / \mathrm{kg}$ ), making the process economically viable.

\section{RECOVERY OF THE EXTRACTED METALS FROM THE CHELATE BY PRECIPITATION}

To recover the metals extracted by the chelate a metal extraction system based on sulphur precipitation was investigated. This method was investigated because metals have a great affinity to precipitate in the presence of sulphur anions, ensuring high levels of extraction. The source of sulphur anions was chosen to be $\mathrm{H}_{2} \mathrm{~S}$. Gaseous $\mathrm{H}_{2} \mathrm{~S}$ was chosen for several reasons. Firstly, because the $\mathrm{H}_{2} \mathrm{~S}$ can be recycled by burning the precipitated complexes of metalsulphur in a hydrogen flame. This extraction ensures recycling of $\mathrm{H}_{2} \mathrm{~S}$ which would lead to less running costs. A source of Sulphur in a solid form was not favoured for this process. If a source of solid Sulphur was used e.g. $\mathrm{Na}_{2} \mathrm{~S}$, the metal from the compound $\left(\mathrm{Na}^{+}\right)$would be difficult to recycle and it would also accumulate in the system. The sulphide in the metal-sulphide-complex would also have to be recovered in a separate process. Secondly, gaseous $\mathrm{H}_{2} \mathrm{~S}$ can be handled in a closed system fairly easily. Thirdly, because $\mathrm{H}$ cations in the chelating agent shouldn't have an effect on the amount of metals extracted from soil once the chelating agent is recycled; further investigation can be done on this subject.

Using $\mathrm{H}_{2} \mathrm{~S}$ as a precipitating agent, studies have found recoveries of $99.7 \%$ Cadmium, 99.8\% Copper, $47.8 \%$ Nickel, $100 \%$ for lead and $92-100 \%$ Zinc [22], [23]. Although the studies were conducted on waste mine water, it is also applicable to chelating agents as well. These amounts of recovery were used in the economic analysis to assess the cost of the system.

\section{MASS BALANCE}

Assumptions:

1. Column extraction method used.

2. Basis of $1 \mathrm{~kg}$ contaminated soil.

3. Flow rate of $2 \mathrm{ml}$ chelating solution $/ \mathrm{min}=120 \mathrm{~L}_{\mathrm{sol}} / \mathrm{h}$ [21].

4. Four washing cycles $=1 \mathrm{~h}$.

5. $20 \mathrm{mM}$ solution of extracting agent is used [21].

6. Maximum metal amounts in any soil:
a. $\mathrm{Cd}-500 \mathrm{mg} / \mathrm{kgsoil}$
b. $\mathrm{Cu}-600 \mathrm{mg} / \mathrm{kgsoil}$
c. $\mathrm{Ni}-3000 \mathrm{mg} / \mathrm{kgsoil}$
d. $\mathrm{Pb}-15000 \mathrm{mg} / \mathrm{kgsoil}$
e. $\mathrm{Zn}-8000 \mathrm{mg} / \mathrm{kgsoil}$

7. Maximum amounts of each metal extracted after one washing cycle:
a. $\mathrm{Cd}-67 \%[21]$
b. $\mathrm{Cu}-56 \%$ [19];
c. $\mathrm{Ni}-25 \%[10]$;
d. $\mathrm{Pb}-90 \%[19]$;
e. $\mathrm{Zn}-60 \%$ [19].

8. $100 \%$ recycle of EDTA and $\mathrm{H}_{2} \mathrm{~S}$. 


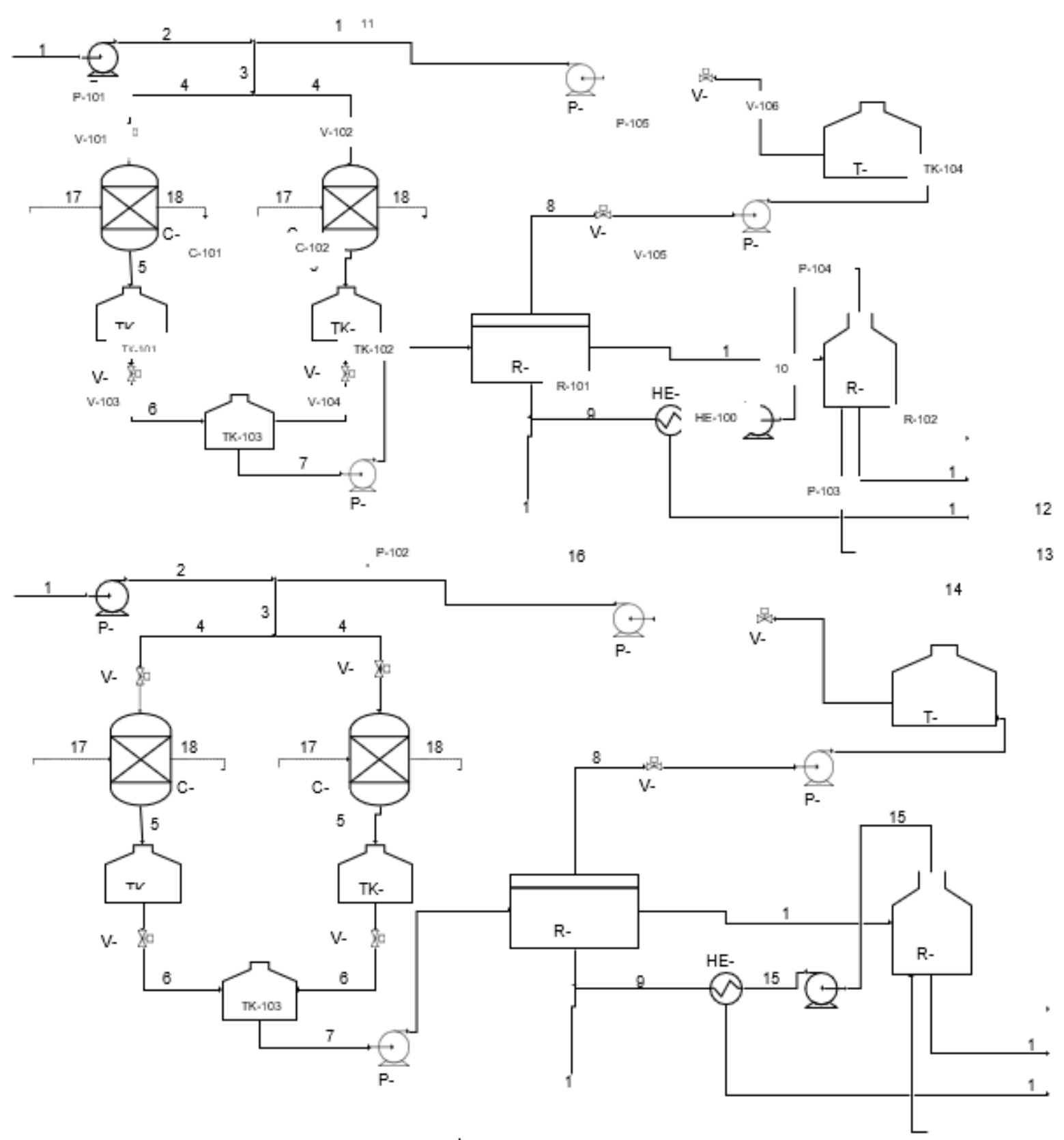

Fig. 2. Process flow diagram of metal recovery process from M-EDTA complex using $\mathrm{H}_{2} \mathrm{~S}$ Leaching columns- C-101, C-102, Leaching storage tanks - TK101, TK-102; Feed storage tank - TK-103; Recycling storage tank - TK-104; $\mathrm{H}_{2} \mathrm{~S}$ Treatment Reactor - R-101; H2 Treatment Reactor - R-102.

Calculations:

EDTA used:

$n=C \cdot V=0.02 \frac{\mathrm{mol}_{\text {chel }}}{L_{\text {sol }}} \cdot 120 \frac{L_{\text {sol }}}{h}=2.4 \frac{\mathrm{mol}_{\text {chel }}}{h}$

Amounts of metals extracted:

$=$ max amount metal $\cdot$ amount extracted $\div$

$M M_{\text {metal }}=x \frac{\text { mol }_{\text {metal }}}{h}$

TABLE V: AMOUNT OF METAL EXTRACTEd Using the BASIC ASSUMPTIONS AND EQUATION 4 FOR COMMUTATION

\begin{tabular}{cc}
\hline Metal & $\begin{array}{c}\text { Amount of metals } \\
\text { extracted }(\mathrm{mol} / \mathrm{hr})\end{array}$ \\
\hline $\mathrm{Cd}$ & $2.98 \times 10^{-3}$ \\
$\mathrm{Cu}$ & $5.29 \times 10^{-3}$ \\
$\mathrm{Ni}$ & $13.23 \times 10^{-3}$ \\
$\mathrm{~Pb}$ & $21.72 \times 10^{-3}$ \\
\hline $\mathrm{Zn}$ & $23.67 \times 10^{-3}$ \\
\hline \multicolumn{2}{l}{ Total metal extracted: $66.89 \times 10^{-3}$} \\
\hline
\end{tabular}

Precipitation of metals with $\mathrm{H}_{2} \mathrm{~S}$ :
$1 \mathrm{~mol} \mathrm{H}_{2} \mathrm{~S}$ : 1 mol M-EDTA [19], so that:

$$
\mathrm{S}^{2-}: \mathrm{M}^{2+}=1: 1
$$

Therefore,

$$
\mathrm{H}_{2} \mathrm{~S} \text { needed }=66.89 \cdot 10^{-3} \frac{\mathrm{mol}}{\mathrm{h}}
$$

This implies that $66.89 .10^{-3} \mathrm{~mol} / \mathrm{h}$ amount of $\mathrm{H}_{2} \mathrm{~S}$ will be needed to recover $66.89 \times 10^{-3} \mathrm{~mol}$ of metals from its complex.

\section{CONCLUSION}

The study has established that recovery of metals from contaminated sources using soil washing techniques could be sustainably achieved from two beneficial points of view. The potential for revenue generation by adopting scenario 2 as depicted in Figure 1 (at least offsetting cost incurred for soil 
remediation activities) and secondly, for metal clean up for the purposes of environmental and human health protection.

\section{REFERENCES}

[1] S. Doumett, L. Lamperi, L. Checchini, E. Azzarello, S. Mugnai, S. Mancuso, G. Petruzzelli, M. Del Bubba, "Heavy metal distribution between contaminated soil and Paulownia tomentosa, in a pilot-scale assisted phytoremediation study: influence of different complexing agents," Chemosphere, vol. 72, no. 10, pp. 1481-1490, 2008.

[2] J. Nouri, A. Mahvi, A. Babaei, G. Jahed, E. Ahmadpour, "Investigation of heavy metals in groundwater," Pakistan journal of biological sciences, vol. 9, no. 3, pp. 377-384, 2006.

[3] B. J. Alloway, "Sources of heavy metals and metalloids in soils," Heavy metals in soils. Springer, pp. 11-50, 2013.

[4] C. N. Neale, R. Bricka, A. C. Chao, "Evaluating acids and chelating agents for removing heavy metals from contaminated soils," Environmental Progress \& Sustainable Energy, vol. 16, no 4, pp. 274280, 1997.

[5] H. A. Elliott, and N. L. Shastri, "Extractive decontamination of metalpolluted soils using oxalate: Water, Air, \& Soil Pollution," [Water Air Soil Pollut], vol. 110, no. 3-4, pp. 335-346, Mar 1999.

[6] R. Bassi, S. O. Prasher, B. K. Simpson, "Removal of Selected Metal Ions from Aqueous Solutions Using Chitosan Flakes," Separation Science and Technology, vol. 35, no. 4, pp. 547-560, 2000

[7] J. Labanowski, F. Monna, A. Bermond, P. Cambier, C. Fernandez, I. Lamy, F. Oort, (2008). "Kinetic extractions to assess mobilization of $\mathrm{Zn}, \mathrm{Pb}, \mathrm{Cu}$, and $\mathrm{Cd}$ in a metal-contaminated soil: EDTA vs. citrate,'Environmental pollution (Barking, Essex : 1987),Vol. 152, pp 693-701, 2008

[8] D. Leštan, C.-L. Luo, X.-D. Li, "The use of chelating agents in the remediation of metal-contaminated soils: a review," Environmental Pollution, vol. 153, no. 1, pp. 3-13, 2008.

[9] L. Hauser, S. Tandy, R. Schulin, B. Nowack, "Column extraction of heavy metals from soils using the biodegradable chelating agent EDDS," Environmental Science \& Technology, vol. 39, no. 17, pp. 6819-6824, 2005.

[10] M. A. Mohamed, A. Efligenir, J. Husson, J. Persello, P. Fievet, N. Fatin-Rouge, "Extraction of heavy metals from a contaminated soil by reusing chelating agent solutions," Journal of Environmental Chemical Engineering, vol. 1, no. 3, pp. 363-368, 2013.

[11] A. Barona, I. Aranguiz, A. Alias, "Metal associations in soils before and after EDTA extractive decontamination: implications for the effectiveness of further clean-up procedures" Environmental Pollution Elseivier, Vol. 113, issue 1, pp 79-85, 2001

[12] X. Zhang, T. Zhong, L. Liu, X.Ouyang, "Impact of Soil Heavy Metal Pollution on Food Safety in China", Plos One, Vol. 10 pp 8, 2015.

[13] N. Finzgar, D. Lestan, "Multi-step leaching of $\mathrm{Pb}$ and $\mathrm{Zn}$ contaminated soils with EDTA", Chemosphere. Vol. 66, no.5, pp. 824-32, 2007

[14] Z. Zou, R. Qiu, W. Zhang, H. Dong, Z. Zhao, T. Zhang, X. Wei, X. Cai, "The study of operating variables in soil washing with EDTA", Environmental Pollution, Vol. 157, Issue 1, pp. 229-236, 2009.

[15] M. Fabbricino, A. Ferraro, G. Del, G. "Current views on EDDS use for ex situ washing of potentially toxic metal contaminated soils", Review in Environmental Science and Biotechnology Vol. 12, pp. 391-398 2013.

[16] L. Mgbeahuruike, J. Barrett, J. H Potgieter, D. L van, Li, S. PotgieterVermaak, "A Comparison of Batch, Column and Heap Leaching Efficiencies for the Recovery of Heavy Metals from Artificially Contaminated Simulated Soil," Journal of Environmental Protection, vol 10, pp. 632-650, 2019.

[17] L. Di Palma, P. Ferrantelli, F. Medici, "Heavy metals extraction from contaminated soil: recovery of the flushing solution," Journal of Environmental Management, vol. 77, no. 3, pp. 205-211, 2005.

[18] R. Wuana, F. Okieimen, J. Imborvungu, "Removal of heavy metals from a contaminated soil using organic chelating acids," International Journal of Environmental Science \& Technology, vol. 7, no. 3, pp. 485496, 2010.

[19] P. A. Hong, C. Li, S. K. Banerji, T. Regmi, "Extraction, recovery, and biostability of EDTA for Remediation of heavy metal-contaminated soil," Journal of Soil Contamination, vol. 8, no. 1, pp. 81-103, 1999.

[20] H. E. Allen, P. H. Chen, "Remediation of metal contaminated soil by EDTA incorporating electrochemical recovery of metal and EDTA," Environmental Progress \& Sustainable Energy, vol. 12, no. 4, pp.284 293, 1993.

[21] Q. Zeng, S. Sauve, H. Allen, W. Hendershot, "Recycling EDTA solutions used to remediate metal-polluted soils," Environmental Pollution, vol. 133, no. 2, pp. 225-231, 2005.
[22] M. T. Alvarez, C. Crespo, B. Mattiasson, "Precipitation of Zn (II), Cu (II) and $\mathrm{Pb}$ (II) at bench-scale using biogenic hydrogen sulfide from the utilization of volatile fatty acids," Chemosphere, vol. 66, no. 9, pp. 1677-1683, 2007.

[23] H. H. Tabak, R. Scharp, J. Burckle, F. K. Kawahara, R. Govind, "Advances in biotreatment of acid mine drainage and biorecovery of metals: 1. Metal precipitation for recovery and recycle" Biodegradation, vol. 14, no. 6, pp. 423-436, 2003. 